\title{
Do environmental preferences in wealthy nations persist in times of crisis? The European environmental attitudes (2008-2017)
}

\author{
Cotta Benedetta ${ }^{1 \star}$ and Memoli Vincenzo ${ }^{2}$ \\ ${ }^{1}$ Faculty of Sustainability, Leuphana Universität Lüneburg, Luneburg, Niedersachsen, Germany and ${ }^{2}$ Università degli \\ Studi di Catania, Catania, Italy \\ ${ }^{*}$ Corresponding author. E-mail: cotta@leuphana.de
}

(Received 21 December 2017; revised 9 January 2019; accepted 23 January 2019; first published online 14 March 2019)

\begin{abstract}
How do economic recessions affect European citizens' attitudes towards environmental policies? In this article we investigate the attitudes of European citizens towards environmental protection considering its importance both at individual and country levels and adopting a longitudinal view. In light of the existing research on the link between pro-environmental attitudes and economic affluence of societies, including Ronald Inglehart's theory of post-materialism, we hypothesise that levels of economic well-being as well as trust in political institutions are important drivers of Europeans' attitudes towards environmental protection. Taking into consideration some macroeconomic indicators and the environmental attitude of public opinion, our main results show that even in time of crises, citizens' pro-environmental attitudes persist in terms of importance, both at country and individual levels.
\end{abstract}

Keywords European Union; environmental policy; public opinion

\section{Introduction}

On 21 June 2018, the Euro-group that coordinates the European Union (EU) member states' adoption of the euro currency agreed to phase out financial aid to Greece, which also posed an end to the sovereign debt crisis in the Eurozone countries (The Guardian, 2018). This decision marks an important step in the recent history of the EU, since the global crises ${ }^{1}$ of 2008 . While it is still too early to understand how this decision will change policy directions across the EU, we can analyse whether and how, over the past decade, the global crises have had repercussions for European policy-making and public opinion's attitudes. In doing so, we examine the citizens' attitudes of the EU member states ${ }^{2}$ on environmental protection, considered as a leading concern of EU's policy-making (see Zito, 2005; Kelemen and Vogel, 2010).

\footnotetext{
${ }^{1}$ Following Falkner (2016a), in this article we use the terms 'global crises', 'economic and financial crises', or simply 'crises' to indicate the 'conglomerate of specific but interconnected crises' (Falkner, 2016a: 220), namely a banking crisis and a sovereign debt crisis, that hit the EU member states following the collapse of the Lehman Brothers' investment bank in 2008. These crises had repercussions on EU's and member states' economic developments, causing also a general feeling of distrust towards banks (Falkner, 2016a), as well as between EU countries (Cotta, 2017).

${ }^{2}$ In our analysis, we assume that the EU member states are 'wealthy' countries. Our assumption is justified by the fact that the EU member states score at the top in several well-known statistical indexes, which rank countries worldwide in terms of economy and human development, that is, the World Bank's Country Income Groups, the International Monetary Fund's World Economic Outlook, and the Human Development Index of the United Nations Development Programme. For more details, see: https://datahelpdesk.worldbank.org/knowledgebase/articles/906519-world-bank-country-and-lending-groups; https://www.imf. org/external/datamapper/PPPPC@WEO/OEMDC/ADVEC/WEOWORLD/EU; http://hdr.undp.org/en/composite/trends.
} 
It is particularly relevant to study how the global crises affected environmental attitudes and policies in the EU because the uptake of European measures for environmental protection has historically depended upon the economic developments of the EU member states (Commission of the European Communities, 1973; Hey, 2005). Initially, the range of the European environmental legislative and policy pieces was limited to specific environmental problems and served economic purposes (Lenschow, 2010). In the 1990s, the promotion of European environmental legislation was constrained by the reluctance of some EU member states to adopt the objectives contained in the Fifth Environmental Action Programme, as well as by the 'pending economic crisis and the difficulties in ratifying the Maastricht Treaty' (Hey, 2005: 24).

The relationship between environmental protection and economic goals in policy-making has been well studied. A first branch of studies focussed on the impact of economic measures on the promotion of environmental policies. At the end of the 19th century, classical economists such as Malthus (1878), de Sismondi (1847), and Mill (1848) identified a link between economic prosperity and environmental issues. In recent times, Grossman and Krueger (1995) observed that low-income countries had initial lower levels of environmental protection, but as wealth increased so did environmental quality. Furthermore, scholars investigating the impact of the 2008 economic and financial crises on the adoption of European environmental legislation and policy instruments acknowledged an existing relationship between economy and environment. Burns and Tobin (2016) developed a 'toolkit' to integrate measures of environmental change in terms of budget cuts, policy outputs, and policy outcomes resulting from the global crises. Furthermore, Falkner (2016a; 2016b) assessed the impact of the ongoing crises in nine EU policies and pointed out that the financial pressures and resulting austerity measures adopted in the EU between 2008 and the early 2015 pushed the member countries to cut public budgets, with consequences for EU climate and energy policies (Falkner, 2016a).

Moreover, the relationship between environmental issues and economic prosperity has been extensively researched by public opinion scholars. Many studies from the literature focussed their analysis on the environment-economy nexus by adopting individuals' perceptions and public attitudes lenses. They subsequently recognised that citizens attributed importance to environmental protection issues subject to socio-political and demographic factors (Van Liere and Dunlap, 1980). Studies also found a correlation between increased levels of economic well-being and concern for the quality of environment (Dunlap and Scarce, 1991; Plombon, 2011; Cato, 2011). Furthermore, several studies focussed on the relationship between individual needs and public attention towards policy issues. Building upon Maslow's (1943) hierarchy of needs, which suggests that in wealthier countries individuals turn their attention towards environmental protection (Kemmelmeier et al., 2002; Plombon, 2011; Kenny, 2018), Ronald Inglehart and co-authors discussed a change in value preference in relation to economic prosperity and environmental protection (Inglehart, 1977; 1990; Inglehart and Abramson, 1999). Inglehart recognised that value orientations towards post-materialist preferences were generally formed before adulthood and 'remained relatively fixed thereafter' (Kenny, 2018: 107; see also Inglehart and Welzel, 2005). Nevertheless, Inglehart also noted that in the presence of extreme socioeconomic conditions, such as economic recessions, orientations could meet fluctuations towards 'a renewed prioritization' of materialist values (Kenny, 2018: 107, referring to Inglehart, 1983).

Although distinct strands of literature recognise a relationship between economic prosperity and environmental protection, there appears to be a little understanding on how situations of economic contraction and austerity such as those triggered by the 2008 global crises could impact public opinion and, specifically, citizens' attitudes towards environmental protection. Several studies identify 'pro-environmental attitude' as the genuine concern that citizens have for existing environmental problems or deteriorating national environmental quality (see, e.g. Dunlap and Scarce, 1991; Kemmelmeier et al., 2002; Franzen and Vogl, 2013; Gifford and Nilsson, 2014). Buttel and Flinn (1976) distinguished between two types of environmental attitude, namely the awareness of existing environmental problems and the public support for governmental efforts to control 
environmental problems through environmental protection measures. Furthermore, Prati et al. (2017) refer to 'pro-environmental behaviour' defining it as individuals' awareness and willingness to take responsibility to act towards environmental protection. In this article, we understand 'proenvironmental attitude' in a broad sense that includes citizens' environmental concern and willingness to take action towards environmental protection, as well as citizens' support towards governmental environmental policy and legislative efforts.

Our understanding of citizens' 'pro-environmental attitude' appears to be particularly important if we consider the role played by public opinion in reaching specific policy outputs. Despite the fact that public opinion does not set the policy agenda (Kingdon, 2003), policies will reflect public opinion's views (Dahl, 1971). Citizens are thus not only able to lead policy change in a specific direction (Hakhverdian, 2012), but in some cases they will also provide a measure of policy performance (Wlezien, 1995). In a systematic analysis linking policy outcomes with public preferences, Franklin and Wlezien (1997) showed a positive public response to specific policy outputs, in this case the European unification. Using the volume of directives adopted by the EC/EU, Toshkov (2011) has further shown that 'a one-year lag to the movements of public opinion and the accumulated effect of public opinion contributes as much as 20 percent of the variation in policy output' (Toshkov 2011: 186). Moreover, a recent study carried out by Anderson et al. (2017) on European public opinion and environmental policies covering the period between 1974 and 2015 found that 'shifts in public opinion in the direction of pro-environmentalism significantly and substantively increase[d] the adoption of renewable energy policies in Europe' (Anderson et al., 2017: 8).

Considering the role played by public opinion attitudes and perceptions in European policymaking, in this article we hypothesise that economic well-being and trust in political institutions have an impact on the environmental attitudes of European citizens. Unlike previous studies, our analysis is carried out considering the importance attributed to the environmental issue at both the country and the individual levels. This distinction is important as in times of crises it is expected that citizens will be more concerned about socio-economic aspects than environmental ones. Furthermore, citizens would less likely make personal efforts to protect the environment and would see environmental protection more as a national than a personal problem (Franzen and Vogl, 2013).

Our focus is on the period in which the global crises significantly impacted the EU member states. In doing so, we aim to understand whether the global financial/economic crises have produced a shift away from pro-environmental preferences in European citizens. The data used to analyse the environmental attitude of Europeans at individual and country level are taken from 16 Eurobarometer surveys ${ }^{3}$ which cover the period between 2002 and 2017. Considering the availability of data, we use the Eurobarmeters and the questions contained in these surveys as proxies to measure citizens' environmental concern and willingness to take environmental action as well as their support towards environmental policy and legislative efforts by governments. Using a hierarchical view of information and adopting a multi-variate analysis, we analyse our pooled data distinguishing the 'green' countries (i.e. Sweden, Austria, Denmark, Finland, and Germany) and the 'PIIGS' countries (i.e. Portugal, Ireland, Italy, Greece, and Spain) from the rest of EU countries under examination. ${ }^{4}$

\footnotetext{
${ }^{3}$ The Eurobarometer datasets considered in this article are the following: n. 88.3 (2017); n. 86.2 (2016); n. 84.3 (2015); n. 82.3 (/2014); n. 80.1 (2013); n. 78.1 (2012); n. 78.1 (2011); n. 76.3 (2010); n. 71.3 (2009); n. 70.1 (2008); n.68.1 (2007); n. 66.3 (2006); n. 64.2 (2005); n. 62.0 (2004); n. 60.1 (2003); n. 57.2 (2002). The data are available at the following link: http:// zacat.gesis.org/webview/index.jsp.

${ }^{4}$ Several studies have classified Sweden, Austria, Denmark, Finland, and Germany as pioneers in adopting environmental protection measures at national level as well as leaders in uploading them at EU level (Wurzel, 2002; Börzel, 2003; Jänicke, 2005; Liefferink et al., 2009). Therefore, we label these EU member states as 'green' countries because of their higher preference towards environmental protection. Moreover, researchers classified Portugal, Ireland, Italy, Greece, and Spain as environmental laggards because they generally resisted or delayed the national implementation of European environmental legislation (Delreux and Happaerts, 2016). We label these EU member states characterised by low levels of preference towards environmental protection with the acronym 'PIIGS'.
} 
The article is structured as follows: in the first section, we review existing research on public opinion's pro-environmental attitudes in wealthy countries and derive our hypotheses on the economic well-being of citizens and their trust in political institutions. In the second section, we provide details on the research design and the methodology used in the empirical part of this study. The third section focusses on the Eurobaromenter surveys, to which we apply a multi-level logistic regression model and analyse the data in a longitudinal approach. Furthermore, we discuss the main findings of the regression model, which show that despite the global crises, between 2008 and 2017 the EU citizens' pro-environmental attitudes have not substantially changed. Finally, we draw some conclusions.

\section{A review of the determinants of citizens' pro-environmental attitudes in wealthy countries}

For four decades, public opinion polls have reflected citizens' preferences towards environmental protection (Van Liere and Dunlap, 1980; Dunlap and Mertig, 2014). The inclusion of environmental protection as a societal issue mirrored an increased public concern towards the existing quality of the environment that began in the United States in the 1960s, with publications foreseeing environmental degradation (e.g. Carson, 1962) and followed by the establishment of nature conservation organizations and citizens' mobilizations (e.g. the Earth Day of 1970). Since then, the relationship between citizens' concern over the quality and the current state of the environment and increased pro-environmental attitudes have been observed in less-developed and poor countries (Dunlap, 1994; Inglehart, 1995), but some studies have shown inconsistencies in this link (see, e.g. Brechin and Kempton, 1994; Dunlap and York, 2008).

For industrialised and wealthy countries, a growing body of scholarly works linked proenvironmental attitudes to citizens' quality of life and life satisfaction (Watts and WandesfordeSmith, 1980; Dunlap and Scarce, 1991; Welsh, 1993). Ronald Inglehart explained growing public concern over environmental issues by theorising a shift from materialist to post-materialist values (Davis and Davenport, 1999; Gelissen, 2007; Dunlap and York, 2008). Since the late 1970s, he studied value shifts from materialism to post-materialism in wealthy nations, observing that value preference correlated with respondents' needs and societal goals (Inglehart, 1977; 1990). The materialist values referred to 'the economic aspects of people's life', while the post-materialist ones corresponded to 'higher-order values based on abstract principles of humanitarianism, civil liberties, democratic participation and enhanced quality of life' (Kemmelmeier et al., 2002: 259) and included also a preference for environmental protection (Aoyagi-Usui et al., 2003; Gelissen, 2007). In 1995, Inglehart specifically addressed the issue of public support for environmental protection and pointed out that in wealthy nations, environmental attitudes were conditioned by post-materialist values (Inglehart, 1995). However, the results of several studies examining this link have not always been consistent with Inglehart's hypothesis (Stern et al., 1999; Kemmelmeier et al., 2002; Dunlap and York, 2008).

Nevertheless, Inglehart's theory on post-materialism has provided, in the words of Dunlap and York, 'important insights into basic social change over the past several decades' (Dunlap and York, 2008: 532). Furthermore, if we focus on Inglehart's assumptions that environmental protection is a 'higher-order quality of life value', which is generally addressed with economic prosperity and when civil liberties and democratic participation are assured, it is possible to identify two factors economic well-being and trust in political institutions - which we hypothesise to be important determinants of the attitudes and preferences of European citizens' in this period of global crises.

\section{Economic well-being}

A positive relationship between economy and the environment has been recognised since the 1940s. Maslow's hierarchy of needs (1943) suggested a direct link between the wealth of a 
nation and pro-environmental attitudes (Maslow, 1943). A similar argument was made by Inglehart who built his theory of post-materialism and preference towards environmental issues in wealthy nations (Inglehart, 1995; 1997). This relationship was further supported by public opinion studies focussing on preferences at societies' level (Brechin, 1999; Kemmelmeier et al., 2002; Franzen, 2003; Givens and Jorgenson, 2011) and at the respondents' individual level (Torras and Boyce, 1998; Ferrer-i-Carbonell and Gowdy, 2005; Silva et al., 2012; Laureti, 2014).

The correlation between economic prosperity and citizens' pro-environmental attitudes was also recognised by studies focussing on the citizens' willingness to make financial sacrifices for environmental protection. In this case, researchers found that citizens supported environmental issues only after reaching a certain level of economic prosperity (Arrow et al., 1995; Beckerman, 1992; Fiorino, 2011; Plombon, 2011; Franzen and Vogl, 2013). Moreover, studies found that citizens of wealthy societies were more often willing to pay environmental taxes according to their level of personal wealth (Calvert, 1979; Rasinski, 1989; Durr, 1993; Inglehart, 1995; Elliott et al., 1997; Knight and Messer, 2012). Considering the link between economic well-being and pro-environmental attitudes, we can thus hypothesise that:

Hypothesis 1: Economic well-being favours citizens' pro-environmental attitude.

\section{Trust in political institutions}

Citizens' preference towards environmental protection relates to a support for political action. Studies show that citizens concern with the quality of the environment often leads to governmental action towards the adoption of environmental measures (Buttel and Flinn, 1976; Dunlap and Scarce, 1991) by placing demands on governments to invest in environmental pollution control and nature conservation measures (Perrings and Ansuategi, 2000; Dinda, 2004; Dasgupta et al., 2006; Fiorino, 2011). However, studies addressing post-materialist value shifts reveal a negative relationship between trust and post-materialist values (Van Deth and Scarbrough, 1995; Memoli, 2011; Cheung 2013). Furthermore, research showed that a lack of trust persisted in most industrial democracies where post-materialistic values still played an important role (Norris, 1999; Dalton, 2004; Armingeon and Guthmann, 2014).

However, trust in the decision-making process, in the institutions and their representatives, continues to be a desirable asset for societies, as well as for political systems. As we know, a sufficient level of trust is crucial for the stability and maintenance of political systems and democracy (Listhaug and Ringdal, 2008). Hence, where citizens' preference and policy outcomes are well connected and citizens perceive that a government is producing outcomes and implementing policies consistent with their expectations (Hetherington, 2005), citizens appear satisfied with their political institutions (Memoli, 2013). Conversely, when trust begins to decline, the democratic legitimacy of the political system is endangered (Severs and Mattelaer, 2014).

The studies that connect trust and environmental behaviour have shown mixed results. Franzen and Vogl (2013), using 2010 International Social Survey Programme (ISSP) ${ }^{5}$ dataset and analysing 31 countries, demonstrated that trust in government is positively associated with environmental concern, while Taniguchi and Marshall (2018), using the same dataset and focalising on 30 countries, found that it was connected to more willingness to make economic sacrifices for the environment. Harring (2013) using 2000 ISSP data on 25 countries determined that the willingness to make economic sacrifices for environmental protection was affected by political trust. Fairbrother (2016) using different data sources (ISSP and Pew Research Center

\footnotetext{
${ }^{5}$ The International Social Survey Programme (ISSP) is an international cross-country collaboration programme which conducts annual surveys on different topics relevant for the social sciences. For more information, see http://www.issp.org/ menu-top/home/.
} 
data) pointed out that the effect of political trust on environmental concern was negative or highly inconsistent, and in some cases the relationship was negative.

Scholars also noticed that trust in governments not only facilitated a collective action towards an environmental improvement but could also provide legitimacy to public institutions (Tsang et al., 2009). However, when political institutional performance on environmental protection policies declined, citizens lost trust in their institutions and became dissatisfied. This scenario has been well defined by Delmas and Young (2009) who found a lack of trust when governments did not satisfactorily address the issue of sustainable development, as well as by Gow and Leahy (2005) who focussed their study on the relationship between environmental risks and the lack of trust in governments. Hetherington and Husser (2012) suggested that citizens' trust in political institutions may shape their environmental attitude, but they did not confirm this with empirical evidence. Here we aim to address this evidence gap by testing the following hypothesis:

Hypothesis 2: Trust in the political institutions favours citizens' pro-environmental attitude.

\section{Research design and methodology}

It is well understood that wealthy and industrialized countries with high post-materialist values exhibit pro-environmental attitudes, resulting in the adoption of environmental protection measures (Dunlap and York, 2008). However, what would happen to citizens' environmental perceptions under economic recession and with the adoption of austerity measures? Would we witness a reduction in citizens' pro-environmental attitudes? The study of the recent global crises offers the opportunity to address these questions. During the second half of the last decade, the EU was hit by financial and economic crises, as well as by institutional and demographic ones (Hansen and Gordon, 2014). The European heads of state and government have agreed on a rescue plan for the European banks and a European recovery plan with the aim of injecting a budgetary stimulus to the EU member states' economies. Additionally, the European Central Bank has injected liquidity into the European monetary markets and adopted a series of interest-rate cuts (Hodson, 2010). Nevertheless, post-crises recoveries have been weaker than expected in many European countries, with slow GDP growth and persistent high unemployment rates (Antoshin et al., 2017).

In response, civic protests have spread across the EU, where governments have been seen as responsible for the financial and economic situation by citizens (Anduiza et al., 2013; Hooghe, 2012). The adoption of counter-cyclical policies has increased the fiscal deficit, aggravated by the banking systems' rescue, and the consequential private debt has become a public debt. In some Eurozone countries this scenario has created serious doubts on the future of the single currency and the EU itself, producing imbalances, problems, and tensions within the European monetary union (Volz, 2013). As a consequence, the relationship between citizens and their own national and European institutions has weakened, especially where public debt has increased and austerity measures have been more stringent (Roth et al., 2011). The crises have simultaneously affected the labour market and civil society, eroding the economic stability of families, affecting the future of young people and deepening gender differences in terms of employment, wages, and poverty (Dietrich, 2012; Rocha, 2012; Bettio et al., 2012).

In reaction to the global crises, economic prosperity and political trust have declined in the EU countries. It is therefore reasonable to assume that a 'retrenchment' in public opinion's proenvironmental attitude has also taken place in the EU. In order to investigate this assumption, we test the effects of economic well-being ${ }^{6}$ and trust in political institutions, ${ }^{7}$ our independent

\footnotetext{
${ }^{6}$ As our database is composed of several Eurobarometer surveys for the years 2002-17, we operationalize the 'economic well-being' hypothesis at country and individual levels by looking at 'national economy perception' and 'financial situation'.
} 
variables, on citizens' environmental attitude, our dependent variable. We use information gathered by 16 Eurobarometers covering the years between 2002 and 2017 and measure citizens' environmental preference at both individual and country levels to examine possible differences between these two levels. ${ }^{8}$ The information related to the relevance of the environment issue at country level ${ }^{9}$ is available from Eurobarometer surveys for the years 2002-17, whereas the data for its relevance at individual ${ }^{10}$ level are available for the years 2008-17. Therefore, to account for both levels, we focus on the period between 2008 and 2017.

Although the theme of the environment is not comparable to those related to the economy and inflation/price increase in terms of importance, in the last decade something has changed in the European public opinion. The Eurobarometer surveys reveal that citizens' attitudes towards environmental issues reflected the political and economic events that influenced the European continent in times of crisis. The data show that between 2008 and 2017 the percentage share of those who believe that the theme of the environment is (perceived as) 'more important' has more than doubled, going from just over $4 \%$, in 2008, to almost $9 \%$ in 2017 . Even when the economic crisis and the migratory one were highly relevant issues for the European public opinion, the environment has never been left aside. In fact, if in 2008 the theme of the environment was considered more important than other issues such as immigration, foreigners, and terrorism, in 2017 it outclassed issues such as crime and the housing problem in addition to the abovementioned ones. This tendency is found both when the issue is considered among the most important at the country level and when it is evaluated on an individual level.

Deepening the analysis of the trends described above, Figure 1 shows that environmental issues have stimulated public opinion in the period between 2002 and 2017. Between 2002 and 2004 the environment was not a major public concern. Citizens' sensitivity to environmental issues increased following the definition of EU guidelines on air emissions in 2005 (the Thematic Strategy on air protection ${ }^{11}$ ). As a result, the support for environmental protection at country level increased by almost $10 \%$ in 2006 compared to 2005, although this was a shortterm effect. Between 2008 and 2011, citizens' positive attitudes towards environmental issues decreased, with differences between individual and country levels. One explanatory factor could be linked to public concern about the economic crises and the prospect of cuts in governmental expenditures (Van der Heijden, 2010; Franzen and Vogl, 2013). Nevertheless, from 2011, concern for the environment increased, particularly at an individual level, until 2015 where it began to decline. Conversely, from 2016 onwards pro-environmental attitudes increased at the country level.

Table 1 displays the percentage of variation in environmental attitudes among EU countries between 2008 and 2017. It can be observed that environmental issues are found to be more important

For the former, the question formulated in the Eurobarometer surveys is the following: 'How would you judge the current situation in each of the following: The situation of the (NATIONALITY) economy'. The variable was recoded in the following way: 1 , who answers 'very good + rather good' and 0 , who indicates 'very bad + rather bad'. For the latter, the question formulated is the following: 'How would you judge the current situation in each of the following: The financial situation of your household. The variable was recoded in the following way: 1 , who answers 'very good + rather good' and 0 , who indicates 'very bad + rather bad'.

${ }^{7}$ In our analysis, we measure 'trust in political institutions' by adding an additive index that aggregates who has trust in the government and in the parliament among the respondents of the Eurobarometers under examination.

${ }^{8}$ As pointed out by Bevan et al. (2015), an issue that is important for the country (socio-tropic view) may not be seen as important at an individual level (egocentric view), and vice versa.

${ }^{9}$ The question formulated at country level is the following: What do you think are the two most important issues facing (OUR COUNTRY) at the moment? The variable was coded in the following way: 1, who answers 'The environment, climate and energy issues' and 0 , who indicates a different issue.

${ }^{10}$ The question formulated at individual level is the following: And personally, what are the two most important issues you are facing at the moment? The variable was coded in the following way: 1, who answers 'The environment, climate and energy issues' and 0 , who indicates a different issue.

${ }^{11}$ For detailed information on this strategy, see http://ec.europa.eu/environment/archives/cafe/pdf/strat_com_en.pdf. 


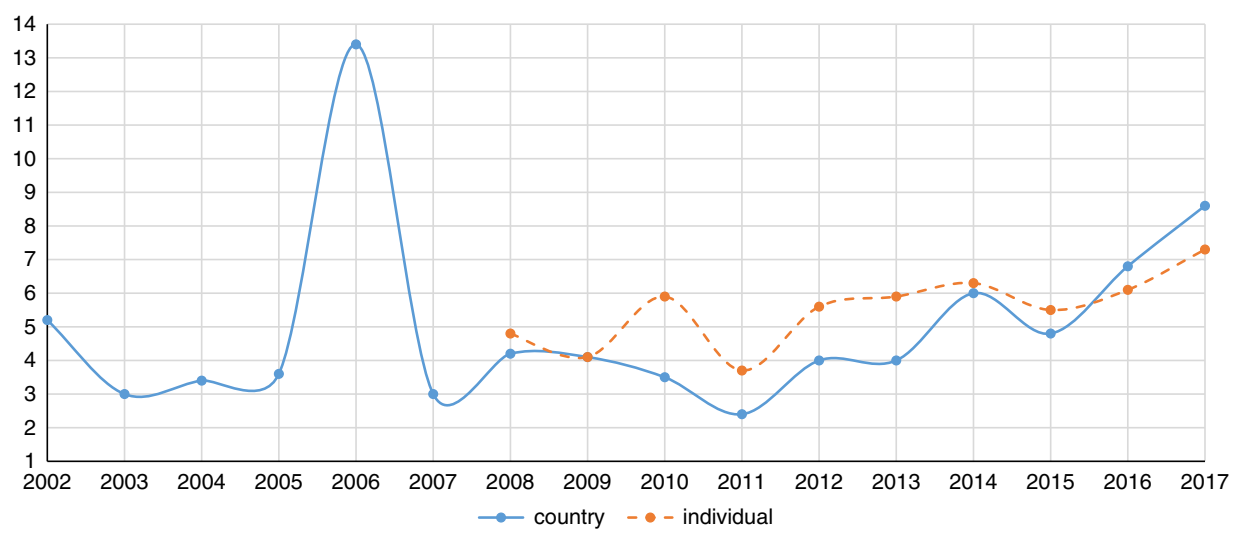

Figure 1. The salience of the environmental issue over time

Source: Eurobarometer (88.3/2017; 86.2/2016; 84.3/2015; 82.3/2014; 80.1/2013; 78.1/2012; 76.3/2011; 73.4/2010; 71.3/2009; 70.1/2008; $68.1 / 2007 ; 66.3 / 2006 ; 64.2 / 2005 ; 62 / 2004 ; 60.1 / 2003 ; 57.2 / 2002)$.

Table 1. Percentage variation in the salience of the environment issue (2008-17)

\begin{tabular}{|c|c|c|}
\hline & Country & Personal \\
\hline Austria & 7.0 & -0.4 \\
\hline Belgium & 6.5 & 0.3 \\
\hline Bulgaria & 1.7 & 0.6 \\
\hline Croatia & 0.9 & -0.6 \\
\hline Cyprus & 1.8 & -1.9 \\
\hline Czech Republic & 2.7 & -1.6 \\
\hline Denmark & 15.1 & -1.7 \\
\hline Estonia & 1.1 & -0.7 \\
\hline Finland & 2.9 & -0.6 \\
\hline France & 4.0 & -1.8 \\
\hline Germany & 14.2 & 5.0 \\
\hline Greece & -4.1 & -3.9 \\
\hline Hungary & 4.3 & 1.5 \\
\hline Ireland & 4.3 & 1.3 \\
\hline Italy & 2 & 1.4 \\
\hline Latvia & 0.5 & -0.3 \\
\hline Lithuania & 0.3 & -0.4 \\
\hline Luxembourg & 6.4 & 0.2 \\
\hline Malta & 11.7 & 0.8 \\
\hline Netherland & 26.1 & 5.1 \\
\hline Poland & 2.5 & 0.4 \\
\hline Portugal & 9.0 & 0.9 \\
\hline Romania & 3.4 & -0.3 \\
\hline Slovakia & 1.8 & -2.3 \\
\hline Slovenia & -1.8 & -2.2 \\
\hline Spain & 2.0 & 0.1 \\
\hline Sweden & 10.6 & 1.5 \\
\hline United Kingdom & 0.2 & -0.3 \\
\hline
\end{tabular}

Source: Eurobarometer (88.3/2017; 86.2/2016; 84.3/2015; 82.3/2014; 80.1/2013; 78.1/2012; 78.1/ 2011; 76.3/2010; 71.3/2009; 70.1/2008; 68.1/ 2007; 66.3/2006; 64.2/2005; 62/2004; 60.1/2003; 52.2/2002).

at both individual and country levels in $13 \mathrm{EU}$ countries under consideration. Among these countries, Germany and the Netherlands are the countries where pro-environmental attitudes have grown by at least 5.0 percentage points during the period considered. In contrast, in Greece and Slovenia the public attributed less importance to the environment. This is particularly pronounced in Greece where the decrease is $>3.9 \%$. Nevertheless, in half of the EU countries there is a clear contradiction: proenvironmental attitude grows at country level while it decreases at individual level and vice versa. 
Table 2. Environment issue and socio-demographic indicators (\% values)

\begin{tabular}{|c|c|c|c|c|}
\hline & \multicolumn{2}{|c|}{ Country } & \multicolumn{2}{|c|}{ Personal } \\
\hline & 2008 & 2017 & 2008 & 2017 \\
\hline Average & 4.2 & 8.6 & 4.8 & 7.3 \\
\hline \multicolumn{5}{|l|}{ Gender } \\
\hline Man & 4.1 & 9.2 & 5.0 & 7.8 \\
\hline Woman & 4.3 & 8.2 & 4.6 & 6.8 \\
\hline \multicolumn{5}{|l|}{ Occupation } \\
\hline Self-employed & 4.4 & 7.8 & 5.6 & 9.1 \\
\hline Employed & 4.8 & 9.4 & 5.4 & 7.7 \\
\hline Not working & 3.7 & 8.1 & 4.2 & 6.5 \\
\hline \multicolumn{5}{|l|}{ Type of community } \\
\hline Rural area or village & 4.1 & 7.9 & 4.4 & 6.7 \\
\hline Small/middle town & 4.2 & 9.2 & 5.2 & 7.4 \\
\hline Large town & 4.4 & 8.6 & 4.8 & 7.6 \\
\hline \multicolumn{5}{|l|}{ Green countries } \\
\hline No & 3.2 & 6.8 & 4.1 & 6.0 \\
\hline Yes & 9.0 & 19.4 & 8.0 & 14.0 \\
\hline
\end{tabular}

Source: Eurobarometer (70.1/2008; 71.3/2009; 88.3/2017).

As shown in Table 2 covering the period 2008-17, the environmental preferences of Europeans appear complex. In our analysis we consider several socio-demographic characteristics (gender, age, occupation, and type of community), and we also consider the 'green countries'. The longitudinal analysis of data at country and individual levels reveals a central core of environmental supporters among the EU countries. Moreover, comparing the information for the year 2008 with that of 2017, it emerges that women more than men are pro-environment at a country level. This trend includes those who are employed, who live in large towns as well as in the green countries. Among the green countries, pro-environmental attitudes have increased by more than $10 \%$ in 9 years. However, the national scenario differs from the individual level where the environment is more important for men, the self-employed and employed, those who live in small/middle towns, and in green countries.

The findings highlighted by our data appear to underline how among citizens there is not always a homogeneous view of the environmental issue. Despite these differences indicated by the socio-demographic factors, over time a central core of environmental supporters has materialized among the EU countries.

\section{Data analysis}

Our dataset (panel data) is hierarchically organised with one level (respondents) embedded in the other (country), and we thus apply a random logistic regression multilevel model that allows for each observation to be correlated within countries (see Steenbergen and Jones, 2002). This choice is mainly dictated by two aspects: First of all, because the number of countries analysed $(N=28)$ is larger than the number of years considered $(T=10)$; and second, because some important explanatory variables from the analysis, namely unemployment or GDP growth, are time-invariant and constant within countries. In other words, a fixed-effect model would be inappropriate.

We present our environmental model in Table 3, which covers the period 2008-17. To explain citizens' environmental attitudes at individual and country levels, we look at three variables: national economy perception, financial situation, and trust in political institutions. Since it is possible that levels of political trust can be affected by existing negative economic trends and there may be a lag time between economic events and changes in respondents' environmental attitudes, at country level we consider the average GDP growth as well as unemployment levels 
Table 3. Correlates of environmental attitudes (2008-17)

\begin{tabular}{|c|c|c|c|c|c|c|}
\hline & & \multicolumn{2}{|c|}{ Country } & & \multicolumn{2}{|c|}{ Personal } \\
\hline & & Odds ratio & Std. error & & Odds ratio & Std. error \\
\hline National economy (good) & & $1.736^{\star \star}$ & 0.051 & & $1.518^{\star \star}$ & 0.041 \\
\hline Financial situation (good) & & $1.088^{\star \star}$ & 0.027 & & $1.097^{\star \star}$ & 0.026 \\
\hline Government or parliament & & $1.458^{\star \star}$ & 0.047 & & $1.412^{\star \star}$ & 0.043 \\
\hline Government and parliament & & $1.483^{\star \star}$ & 0.038 & & $1.434^{\star \star}$ & 0.035 \\
\hline Gender ( $1=$ woman) & & $1.050^{\star}$ & 0.022 & & $1.047^{\star}$ & 0.022 \\
\hline Age (18-98) & & $0.995^{\star \star}$ & 0.001 & & 0.999 & 0.001 \\
\hline Employed & & $0.895^{\star \star}$ & 0.036 & & $0.870^{\star *}$ & 0.032 \\
\hline Not working & & $0.835^{\star \star}$ & 0.035 & & $0.694^{\star *}$ & 0.026 \\
\hline Small/middle town & & 1.014 & 0.026 & & 1.032 & 0.025 \\
\hline Large town & & $1.176^{\star \star}$ & 0.033 & & $1.206^{\star \star}$ & 0.032 \\
\hline Life satisfaction $\mathrm{t}_{\mathrm{t}-1}$ & & $1.023^{\star \star}$ & 0.003 & & $1.026^{\star \star}$ & 0.003 \\
\hline GDP growth t-3 & & $1.068^{\star \star}$ & 0.019 & & 0.983 & 0.015 \\
\hline Unemployment $_{\mathrm{t}-1}$ & & 0.982 & 0.014 & & $0.976^{\star}$ & 0.012 \\
\hline Green countries: yes & & $2.131^{\star \star}$ & 0.279 & & $1.374^{\star *}$ & 0.155 \\
\hline PIIGS countries: yes & & $0.715^{\star}$ & 0.102 & & $0.755^{\star}$ & 0.091 \\
\hline Constant & & $0.005^{\star \star}$ & 0.002 & & $0.007^{\star *}$ & 0.002 \\
\hline /Insig2u & -0.687 & & 0.104 & -0.980 & & 0.104 \\
\hline sigma_u & 0.709 & & 0.037 & 0613 & & 0.032 \\
\hline Rho & 0.133 & & 0.012 & 0.102 & & 0.010 \\
\hline Number of observations & 194,599 & & & 194,593 & & \\
\hline Number of countries/years & 279 & & & 279 & & \\
\hline Wald $\chi^{2}$ (sig.) & 0.000 & & & 0.000 & & \\
\hline
\end{tabular}

Note: Reference category: national economy: bad; financial situation: bad; confidence in political institutions: no one; gender: man; occupation: self-employed; type of community: rural area or village; green country: no; PIIGS countries: no. ${ }^{\star} P<0.05$; ${ }^{\star \star} P<0.01$.

Source: Eurobarometer (88.3/2017; 86.2/2016; 84.3/2015; 82.3/2014; 80.1/2013; 78.1/2012; 76.3/2011; 73.4/2010; 71.3/2009; 70.1/2008).

for the 3 years preceding each survey. ${ }^{12}$ Furthermore, we control the effect of the two independent variables on the dependent variable by considering several socio-demographic characteristics (gender, ${ }^{13}$ age, ${ }^{14}$ occupation, ${ }^{15}$ type of community ${ }^{16}$ ), and citizens' perception of life satisfaction ${ }^{17}$ for the year preceding each survey. We also add two dummy variables to differentiate environmental attitudes of 'green' and 'PIIGS' countries from the others. ${ }^{18}$

Our findings support our two hypotheses on economic well-being and trust in political institutions. At country level, we observe a correlation between citizens positively evaluating the economy and their attribution of importance to the environment. The positive perception of the national economy as well as the financial situation makes citizens at least 1.088 times more likely to place importance on environmental issues compared to citizens with a negative perception of their national economy and financial situation. In other words, a perceived economic well-being positively correlates with a higher environmental attitude.

Although national economy and financial situation perception appear to correlate with higher public environmentalism, trust in political institutions is also important. This is particularly evident when trust is placed on the two main political institutions, namely in the parliament and

\footnotetext{
${ }^{12}$ The source of data is World Bank.

${ }^{13}$ It is represented by a dummy variable coded in the following way: $0=$ male; $1=$ female.

${ }^{14}$ It is represented by a cardinal variable that goes from 18 to 98 years and older.

${ }^{15}$ It is represented by an ordinal variable coded in the following way: $0=$ self-employed; $1=$ employed; $2=$ not working.

${ }^{16}$ It is represented by an ordinal variable coded in the following way: $0=$ rural area or village; $1=$ small $/$ middle town; $2=$ large town.

${ }^{17}$ The question is 'On the whole, are you very satisfied, fairly satisfied, not very satisfied or not at all satisfied with the life you lead?' The percentage values expressed by the variable represent the level of life satisfaction in the country (very satisfied + fairly satisfied) in the year preceding each survey.

${ }^{18}$ The 'green countries' variable has a value of 1 for Austria, Denmark, Finland, Germany, and Sweden, 0 for the others. The 'PIIGS countries' variable has a value of 1 for Greece, Ireland, Italy, Portugal, and Spain, 0 for the others.
} 
the government of a country. Our data show that the odds of a higher environmental attitude in respondents with trust in these two political institutions are $48.3 \%$ more likely to have a proenvironmental attitude in comparison to respondents without trust in political institutions in general. However, this probability is slightly lower when public trust is placed only in the parliament or in the government.

We find similar trends when we consider the relevance of environmental issues at the individual level. In addition, in this case, the environmental attitudes appear to be strongly influenced by the respondents' perception of the national economy. In fact, a one-unit change in the national economy (from bad to good) increases the odds of environmental sensitivity by a factor of 1.518. Moreover, the perception of the financial situation positively impacts on the dependent variable, but with a much lower probability (1.097) than the perception of the national economy. The institutional trust affects the dependent variable, with a slightly lower probability than that found at the country level.

Our findings support our hypotheses also when controlling for economic and sociodemographic factors. At country level, with sustained economic growth, citizens' attitudes towards the environment are more positive. This result is true among women and those who in the preceding year survey expressed life satisfaction. Furthermore, inhabitants of large towns place more importance on environmental issues. Young people more than adults are more inclined to place importance on the environment, whereas individual employment status does not reveal specific differences in terms of environmental attitudes: both employed and unemployed negatively affect environmental sensitivity. Moreover, in green countries there is a greater likelihood to observe a more positive environmental attitude at country level. On the contrary, among the PIIGS countries environmental sensitivity is probably given to more micro and macro-economic issues and the pro-environmental attitude is lower at a country level. At individual level, women appear to be more sensitive than men to environment (1.047), but only those respondents who live in large towns place greater importance on environmental issues. Similar to the results for the country level, employment status produces a negative effect on the sensitivity to environment, particularly for those who are not working. Citizens of green countries and with higher quality of life appear more inclined towards environmental issues. However, among PIIGS countries or in countries with high unemployment, most citizens do not consider the environment particularly important.

\section{Conclusions}

Many public opinion studies have investigated the motivations for environmental preferences in wealthy nations, pointing to determinants such as a genuine concern for environmental quality, respondents' socio-demographic features, and economic well-being. Several studies explained the increased environmentalism of industrialised nations with a shift from materialist to postmaterialist values. Considering these explanations for citizens' environmental attitudes and their relationship to economic prosperity, with this article we have shifted the focus to investigate the environmental preferences in times of economic recession and austerity, a topic that still appears underexplored in the literature. ${ }^{19}$ Recent research has addressed the impact of the crises on EU policy-making by providing a 'toolkit' to measure environmental change as a result of exogenous shocks, namely the global economic and financial crises (Burns and Tobin, 2016). Moreover, Falkner (2016b) stressed how the crises have not substantially changed the broad objectives of the European climate and energy policies but changed the 'hierarchy of priorities with now much stronger leaning towards economic concerns and - often - fiscal containment' (Falkner 2016a:

\footnotetext{
${ }^{19}$ One exception is the recent study carried out by Kenny (2018). Although not focussing on the EU, he analysed public opinion's environmental preferences during the 2008 global economic and financial crises and found a lack of correlation between the 2008 crises and a decline in public opinion's environmental preference.
} 
228; but on this point see also Slominski, 2016) with the result of shifting the attention away from environmental protection (Slominski, 2016).

Regarding changes in public attitudes following the 2008 global crises, and referring to Inglehart's theorising on post-materialism, we would have expected a shift to less pro-environmental attitudes and a preference shift towards materialistic values, as suggested also by recent studies (e.g. Conroy and Emerson, 2014). However, despite the fact that the global crises affected European governments and citizens' collective economic well-being and political trust, environmental attitudes do not seem to have substantially changed in the EU countries we studied. On the contrary, echoing findings from other studies, we found that between 2008 and 2017 environmental protection remained a priority. Examples of such prioritisation can be found in the lengthy discussions among EU member states on climate change (Chaisty and Whitefield, 2015; Marcinkiewicz and Tosun, 2015), the EU institutions' agenda (Čavoški, 2015), as well as at national level with the issue of compliance with European environmental legislation (Lekakis and Kousis, 2013).

From a longitudinal perspective, the environmental issue is increasingly considered an important issue among European citizens, also when compared with other social, political, and economic issues. In this view, pro-environmental attitudes were supported when environmental issues were considered important at both country and individual levels. Since 2011, motivation at both levels made European citizens increasingly sensitive to the theme of environmental protection. Furthermore, our findings show that environmental attitudes at both individual and country levels have been unevenly distributed between EU countries, as summarised in Tables 1 and 2. Thus, when citizens' attitudes towards environmental issues are more positive at an individual level, they are less positive at a country level, and vice versa. Additionally, the percentage of European citizens considering the environment a highly important issue has increased, particularly when it is evaluated at a country level. Between 2008 and 2017, the environment was regarded as an important issue in almost half of the countries at both the individual and country levels, while in $14 \mathrm{EU}$ countries there was a clear contradiction: positive attitudes towards environmental protection increased at country level while simultaneously decreasing at individual level and vice versa.

Our multi-level logistic regression models (Table 3) on the Eurobarometer data pool (2008-17) identify correlations between economic well-being and environmental attitudes as well as between political institutions and environmental attitudes. Both aspects of economic well-being and trust in political institutions appear to positively correlate with a higher environmental attitude. Hence, when the economy is strong, citizens are more inclined to attribute importance to environmental issues, even in presence of low trust in the political institutions. On the contrary, when economic performance is poor, citizens tend to prioritise other issues and to view environmental issues as of governmental concern. Furthermore, unlike trust in political institutions, the positive correlation between strong economic performance and environmental attitudes persists at both country and individual levels. We recognise that these findings cannot be generalised to all European citizens and countries under examination. Moreover, in countries with economic prosperity and a greater adoption of environmental protection measures, namely the green countries, citizens' pro-environmental attitude is greater.

Despite these possible limitations, this work offers a first analysis of the relationship between economy and the environment in recent years, primarily revealing how the pro-environmental attitudes of European citizens have persisted even in presence of exogenous shocks. Future directions of study may lead to consider the multi-dimensional nature of environmental problems and the different environmental resources. Furthermore, it could aim to better disentangle the contradictions between the importance of environment at individual and country levels, shedding light on the interdependencies and interactions between different environmental aspects (e.g. water, air, and soil). Moreover, it could expand the spatial dimension of analysis and consider also the local, regional, and international contexts.

Acknowledgements. A previous version of this article was presented at the ECPR General Conference 2015 in the panel on 'Green Parties and Partisan Politics'. We thank the panel participants and chairs for the stimulating discussions. We are also 
grateful to Maurizio Cotta, Jens Newig, and Maria Ravlik for reading and providing valuable comments on earlier drafts, to Emmeline Topp for her edits as well as to two anonymous reviewers for their insightful and helpful suggestions.

Financial support. The research received no grants from public, commercial, or non-profit funding agency.

Data. The replication dataset is available at http://thedata.harvard.edu/dvn/dv/ipsr-risp.

\section{References}

Anderson B, Tobias B and Hugh W (2017) Public opinion and environmental policy output: a cross-national analysis of energy policies in Europe. Environmental Research Letters 12(11): 1-10.

Anduiza E, Christanco C and Sabucedo JM. (2013) Mobilization through online social networks: the political protest of the indignados in Spain. Information, Communication, and Society 17(6): 750-764.

Antoshin S, Arena M, Gueorguiev N, Lybek T, Ralyea J and Yehoue EB (2017) Credit growth and economic recovery in Europe after the global financial crisis. IMF Working Papers 17/253, 1-54.

Aoyagi-Usui M, Vinken $\mathbf{H}$ and Kuribayashi A (2003) Pro-environmental attitudes and behaviors: an international comparison. Human Ecology Review 10(1): 23-31.

Armingeon K and Guthmann K (2014) Democracy in crisis? The declining support for national democracy in European countries, 2007-2011. European Journal of Political Research 53(3): 423-442.

Arrow K, Bolin B, Costanza R, Dasgupta P, Folke C and Holling CS (1995) Economic growth, carrying capacity, and the environment. Science 268(5210): 520-521.

Beckerman W (1992) Economic growth and the environment: Whose growth? Whose environment? World Development 20 (4): 481-496.

Bettio F, Corsi M, D’Ippoliti C, Lyberaki A, Lodovici MS and Verashchagina A (2012) The Impact of the Economic Crisis on the Situation of Women and Men and on Gender Equality Policies. European Commission, Luxembourg: European Union.

Bevan S, Jennings W and Wlezien C (2015) An analysis of the public's personal, national and EU issue priorities. Journal of European Public Policy 23(6): 871-887.

Börzel TA (2003) Environmental Leaders and Laggards in Europe: Why There Is (Not) a Southern Problem. Aldershot: Ashgate.

Brechin SR (1999) Objective problems, subjective values, and global environmentalism: Evaluating the postmaterialist argument and challenging a new explanation. Social Science Quarterly 80(4): 793-809.

Brechin SR and Kempton W (1994) Global environmentalism: a challenge to the postmaterialism thesis? Social Science Quarterly 75(2): 245-269.

Burns CJ and Tobin P (2016) The impact of the economic crisis on European Union environmental policy. Journal of Common Market Studies 54(6): 1485-1494.

Buttel FH and Flinn WL (1976) Economic growth versus the environment: survey evidence. Social Science Quarterly 57(2): 410-420.

Calvert JW (1979) The social and ideological bases of support for environmental legislation: an examination of public attitudes and legislative action. The Western Political Quarterly 32(3): 327-337.

Carson R (1962) Silent Spring. Boston: Houghton Mifflin.

Cato SM (2011) Environment and Economy. London: Routledge.

Čavoški A (2015) A post-austerity European Commission: no role for environmental policy? Environmental Politics 24(3): 501-505.

Chaisty P and Whitefield S (2015) Attitudes towards the environment: are postcommunist societies (still) different? Environmental Politics 24(4): 598-616.

Cheung C (2013) Postmaterialist Influences on Welfare Adequacy and Political Trust in Hong Kong. Journal of Comparative Asian Development 12(1): 147-179.

Commission of the European Communities (1973) Programme of the environmental action of the European Communities'. Bulletin of the European Communities, Supplement 3/1973.

Conroy SJ and Emerson TLN (2014) A tale of trade-offs: the impact of macro-economic factors on environmental concern. Journal of Environmental Management 145, 88-93.

Cotta M (2017) Un'altra Europa è possibile - Che fare per salvarla. Il Mulino.

Dahl R (1971) Polyarchy: Participation and Opposition. New Haven, CT: Yale University Press.

Dalton RJ (2004) Democratic Challenges, Democratic Choices: The Erosion in Political Support in Advanced Industrial Societies. Oxford: Oxford University Press.

Dasgupta S, Hamilton K, Pandey KD and Wheeler D (2006) Environment during growth: accounting for governance and vulnerability. World Development 34(9): 1597-1611.

Davis DW and Davenport C (1999) Assessing the validity of the postmaterialism index. American Political Science Review 93(3): 649-664. 
de Sismondi JCLS (1847) Political Economy, and The Philosophy of Government; A Series of Essays Selected from the Works of M. De Sismondi, Transl. London: John Chapman.

Delmas MA and Young OR (2009) Governance for the Environment: New Perspectives. Cambridge: Cambridge University Press.

Delreux T and Happaerts S (2016) Environmental Policy and Politics in the European Union, Palgrave Macmillan.

Dietrich H (2012) Youth Unemployment in Europe. Theoretical Considerations and Empirical Findings. Berlin: Friedrich Ebert-Stiftung.

Dinda S (2004) Environmental Kuznets curve hypothesis: a survey. Ecological Economics 49(4): 431-455.

Dunlap RE (1994) International attitudes towards environment and development. Green Globe Yearbook of International Co-operation on Environment and Development 1994, 115-126.

Dunlap RE and Scarce R (1991) Poll trends: environmental problems and protection. The Public Opinion Quarterly 55(4): 651-672.

Dunlap RE and York R (2008) The globalization of environmental concern and the limits of the postmaterialist values explanation: evidence from four multinational surveys. The Sociological Quarterly 49(3): 529-563.

Dunlap RE and Mertig AG (2014) Trends in public opinion toward environmental issues: 1965-1990. American Environmentalism 4(3): 209-218.

Durr RH (1993) What moves policy sentiment? American Political Science Review 87(1): 158-170.

Elliott E, Seldon BJ and Regens JL (1997) Political and economic determinants of individuals' support for environmental spending. Journal of Environmental Management 51(1): 15-27.

Fairbrother M (2016) Trust and public support for environmental protection in diverse national contexts. Sociological Science 3, 359-382.

Falkner G (2016a) The EU's current crisis and its policy effects: research design and comparative findings. Journal of European Integration 38(3): 219-235.

Falkner G (2016b) The EU's problem-solving capacity and legitimacy in a crisis context: a virtuous or vicious circle? West European Politics 39(5): 953-970.

Ferrer-i-Carbonell A and Gowdy J (2005) 'Environmental Awareness and Happiness'. Rensselaer Working Papers in Economics, 0503.

Fiorino DJ (2011) Explaining national environmental performance: approaches, evidence, and implications. Policy Sciences 44(4): 367-389.

Franklin MN and Wlezien C (1997) The responsive public: issue salience, policy change, and preferences for European unification. Journal of Theoretical Politics 9(3): 347-363.

Franzen A (2003) Environmental attitudes in international comparison: an analysis of the ISSP surveys 1993 and 2000 . Social Science Quarterly 84(2): 297-308.

Franzen A and Vogl D (2013) Two decades of measuring environmental attitudes: a comparative analysis of 33 countries. Global Environmental Change 23(5): 1001-1008.

Gelissen J (2007) Explaining popular support for environmental protection: a multilevel analysis of 50 nations. Environment and Behavior 39(3): 392-415.

Gifford R and Nilsson A (2014) Personal and social factors that influence pro-environmental concern and behaviour: a review. International Journal of Psychology 49(3): 141-157.

Givens JE and Jorgenson AK (2011) The effects of affluence, economic development, and environmental degradation on environmental concern: a multilevel analysis. Organization \& Environment 24(1): 74-91.

Gow J and Leahy T (2005) Apocalypse probably: agency and environmental risk in the Hunter region. Journal of Sociology 41(2): 117-141.

Grossman GM and Krueger AB (1995) Economic environment and the economic growth. Quarterly Journal of Economics 110(2): 353-377.

Hakhverdian A (2012) The causal flow between public opinion and policy: government responsiveness, leadership, or counter movement? West European Politics 35(6): 1386-1406.

Hansen R and Gordon JC (2014) Deficits, democracy, and demographics: Europe's three crises. West European Politics 37 (6): 1199-1222.

Harring N (2013) Understanding the effects of corruption and political trust on willingness to make economic sacrifices for environmental protection in a cross-national perspective. Social Science Quarterly 94(3): 660-671.

Hetherington MJ (2005) Why Trust Matters: Declining Political Trust and the Demise of American Liberalism. Princeton, NJ: Princeton University Press.

Hetherington MJ and Husser JA (2012) How trust matters: the changing political relevance of political trust. American Journal of Political Science 56(2): 312-325.

Hey C (2005) EU environmental policies: a short history of the policy strategies. In European Environmental Bureau, In Stefan Scheuer (ed.). EU Environmental Policy Handbook. A Critical Analysis of EU Environmental Legislation. Brussels: European Environmental Bureau, 17-30.

Hodson D (2010) The EU economy: The euro area in 2009. Journal of Common Market Studies 48(1): 225-242. 
Hooghe M (2012) Taking to the streets. Harvard International Review 34(2): 34-38.

Human Development Index of the United Nations Development Programme. Retrieved from http://hdr.undp.org/en/ composite/trends.

Inglehart R (1977) Long term trends in mass support for European unification. Government and Opposition 12(2): $150-177$.

Inglehart R (1983) The persistence of materialist and post-materialist value orientations: comments on Van Deth's analysis. European Journal of Political Research 11(1): 81-91.

Inglehart R (1990) Culture Shift in Advanced Industrial Society. Cambridge, UK: Princeton University Press.

Inglehart R (1995) Public support for environmental protection: objective problems and subjective values in 43 societies. Political Science \& Politics 28(1): 57-72.

Inglehart R (1997) Modernization and Postmodernization. Cultural, Economic, and Political Change in 43 Societies. Princeton, New Jersey: Princeton University Press.

Inglehart R and Abramson PR (1999) Measuring postmaterialism. American Political Science Review 93(3): 665-677.

Inglehart R and Welzel C (2005) Modernization, Cultural Change, and Democracy: The Human Development Sequence. Princeton, NJ: Cambridge University Press.

International Monetary Fund's World Economic Outlook. Retrieved from https://www.imf.org/external/datamapper/ PPPPC@WEO/OEMDC/ADVEC/WEOWORLD/EU.

International Social Survey Programme. Retrieved from http://www.issp.org/menu-top/home/.

Jänicke M (2005) Trend-setters in environmental policy: the character and role of pioneer countries. European Environment 15(2): 129-142.

Kelemen DR and Vogel D (2010) Trading places: the role of the United States and the European Union in international environmental politics. Comparative Political Studies 43(4): 427-456.

Kemmelmeier M, Krol G and Kim YH (2002) Values, economics, and proenvironmental attitudes in 22 societies. CrossCultural Research 36(3): 256-285.

Kenny J (2018) Environmental protection preferences under strain: an analysis of the impact of changing individual perceptions of economic and financial conditions on environmental public opinion during economic crisis. Journal of Elections, Public Opinion and Parties 28(1): 105-124.

Kingdon JW (2003) Agendas, Alternatives, and Public Policies, 2nd edn., New York: Longman.

Knight KW and Messer BL (2012) Environmental concern in cross-national perspective: the effects of affluence, environmental degradation, and World Society. Social Science Quarterly 93(2): 521-537.

Laureti T (2014) 'Life satisfaction and environmental conditions in Italy: a pseudo panel approach'. Collana di E-papers del Dipartimento di Economia e Management - Università di Pisa, Discussion Paper No. 192.

Lekakis JN and Kousis M (2013) Economic crisis, Troika and the environment in Greece". South European Society and Politics 18(3): 305-331.

Lenschow A (2010) 'Environmental policy: contending dynamics of policy change'., In Helen Wallace, Mark A. Pollack and Alasdair R. Young (eds). Policy-Making in the European Union. Oxford: Oxford University Press, 319-343.

Liefferink D and Andersen MS (1998) Strategies of the green member states in EU environmental policy-making. Journal of European Public Policy 5(2): 250-270.

Liefferink D, Arts B, Kamstra J and Ooijevaar J (2009) Leaders and laggards in environmental policy: a quantitative analysis of domestic policy outputs. Journal of European Public Policy 16(5): 677-700.

Listhaug $\mathbf{O}$ and Ringdal K (2008) 'Trust in political institutions'., In Heikki Heikki, Fridberg Torben, Mikae Hjerm and Kirsten Ringdal (eds). Nordic Social Attitudes in a European Perspective. Northampton Massachusetts: Edward Elgar Publishing.

Malthus. TR (1878) An Essay on the Principle of Population: Or, A View of Its Past and Present Effects on Human Happiness, with an Inquiry into Our Prospects Respecting the Future Removal or Mitigation of the Evils Which it Occasions. London: Reeves and Turner.

Marcinkiewicz K and Tosun J (2015) Contesting climate change: mapping the political debate in Poland. East European Politics 31(2): 187-207.

Maslow AH (1943) A theory of human motivation. Psychological Review 50(4): 370-396.

Memoli V (2011) Sostenere la democrazia. Roma: Aracne.

Memoli V (2013) 'Responsiveness', In Leonardo Morlino, Daniela Piana and Francesco Raniolo (eds). La Qualità della democrazia 1992-2012. Bologna: Il Mulino.

Mill JS (1848/2004) Principles of Political Economy. Great Minds Series. Amherst, NY: Prometheus Books.

Norris P ed. (1999) Critical Citizens: Global Support for Democratic Government. Oxford: Oxford University Press.

Perrings C and Ansuategi A (2000) Sustainability, growth and development. Journal of Economic Studies 27(1/2): 19-54.

Plombon E (2011) Factors affecting pro-environmental attitudes. Journal of Undergraduate Research 25, 1-14.

Prati G, Albanesi C and Pietrantoni L (2017) The interplay among environmental attitudes, pro-environmental behavior, social identity, and pro-environmental institutional climate. A longitudinal study. Environmental Education Research 23 (2): 176-191. 
Rasinski KA (1989) The effect of question wording on public support for government spending. Public Opinion Quarterly 53 (3): 388-394.

Rocha SF (2012) 'El desempleo juvenil en España. Situaciones y recomendaciones políticas'. Informe, 50, Fundación $1^{\circ}$ de Mayo.

Roth F, Nowak-Lehmann FD and Otter T (2011) 'Has the financial crisis shattered citizens' trust in national and European governmental institutions? Evidence from the EU member states, 1999-2010'. CESP (Centre for European Policy Studies), 343, June.

Severs E and Mattelaer A (2014) 'A crisis of democratic legitimacy? It's about legitimation, stupid!'. European Policy Bries, n. 21. Brussels: EGMONT.

Silva J, de Keulenaer F and Johnstone N (2012) 'Environmental quality and life satisfaction: evidence based on micro-data'. OECD Environment Working Papers, No. 44. OECD Publishing.

Slominski P (2016) Energy and climate policy: does the competitiveness narrative prevail in times of crisis? Journal of European Integration 38(3): 343-357.

Steenbergen MR and Jones BS (2002) Modeling multilevel data structures. American Journal of Political Science 46(1): 218-237.

Stern PC, Dietz T, Abel T, Guagnano GA and Kalof L (1999) A value-belief-norm theory of support for social movements: the case of environmentalism. Human Ecology Review 6(2): 81-97.

Taniguchi H and Marshall GA (2018) Trust, political orientation, and environmental behavior. Environmental Politics 27 (3): 385-410.

The Guardian (2018). Retrieved from https:/www.theguardian.com/world/2018/jun/22/eurozone-greece-financial-crisisdeal.

Thematic Strategy on air protection. Retrieved from http://ec.europa.eu/environment/archives/cafe/pdf/strat_com_en.pdf.

Torras M and Boyce JK (1998) Income, inequality, and pollution: a reassessment of the environmental Kuznets curve. Ecological Economics 25(2): 147-160.

Toshkov D (2011) Public opinion and policy output in the European Union: a lost relationship. European Union Politics 12 (2): 169-191.

Tsang S, Burnett M, Hills P and Welford R (2009) Trust, public participation and environmental governance in Hong Kong. Environmental Policy and Governance 19(2): 99-114.

Van der Heijden H-A (2010) The Dutch 2010 elections and the environment. Environmental Politics 19(6): 1000-1005.

Van Deth JW and Scarbrough E (1995) The Impact of Values. New York: Oxford University Press.

Van Liere KD and Dunlap RE (1980) The social bases of environmental concern: A review of hypotheses, explanations and empirical evidence. Public Opinion Quarterly 44(2): 181-197.

Volz U (2013) Lessons of the European crisis for regional monetary and financial integration in East Asia. Asia Europe Journal 11(4): 355-376.

Watts N and Wandesforde-Smith G (1980) Postmaterial values and environmental policy change. Policy Studies Journal 9 (3): 346-358.

Welsh D (1993) Domestic politics and ethnic conflict. Survival 35(1): 63-80.

Wlezien C (1995) The public as thermostat: dynamics of preferences for spending. American Journal of Political Science 39 (4): 981-1000.

World Bank Country Income Groups dataset. Retrieved from https://datahelpdesk.worldbank.org/knowledgebase/articles/ 906519-world-bank-country-and-lending-groups.

Wurzel RKW (2002) Environmental Policy-Making in Britain, Germany, and the European Union: The Europeanisation of Air and Water Pollution Control. Manchester: Manchester University Press.

Zito AR (2005) The European Union as an environmental leader in a global environment. Globalizations 2(3): $363-375$.

Cite this article: Cotta B, Memoli V. (2020). Do environmental preferences in wealthy nations persist in times of crisis? The European environmental attitudes (2008-2017). Italian Political Science Review/Rivista Italiana di Scienza Politica 50, 1-16. https://doi: 10.1017/ipo.2019.3 